\title{
Precipitation response to aerosol-radiation and aerosol-cloud interactions in regional climate simulations over Europe
}

\author{
José María López-Romero ${ }^{1}$, Juan Pedro Montávez ${ }^{1}$, Sonia Jerez ${ }^{1}$, Raquel Lorente-Plazas ${ }^{1,2}$, Laura Palacios-Peña ${ }^{1,2}$, \\ and Pedro Jiménez-Guerrero ${ }^{1,3}$ \\ ${ }^{1}$ Physics of the Earth, Regional Campus of International Excellence (CEIR) "Campus Mare Nostrum", \\ University of Murcia, 30100 Murcia, Spain \\ ${ }^{2}$ Department of Meteorology, Meteored, 30893 Murcia, Spain \\ ${ }^{3}$ Biomedical Research Institute of Murcia (IMIB-Arrixaca), 30120 Murcia, Spain
}

Correspondence: Juan Pedro Montávez (montavez@um.es)

Received: 20 April 2020 - Discussion started: 18 May 2020

Revised: 16 November 2020 - Accepted: 25 November 2020 - Published: 14 January 2021

\begin{abstract}
The effect of aerosols on regional climate simulations presents large uncertainties due to their complex and non-linear interactions with a wide variety of factors, including aerosol-radiation (ARI) and aerosol-cloud (ACI) interactions. These interactions are strongly conditioned by the meteorological situation and type of aerosol, but, despite their increase, only a limited number of studies have covered this topic from a regional and climatic perspective.

This contribution thus aims to quantify the impacts on precipitation of the inclusion of ARI and ACI processes in regional climate simulations driven by ERA20C reanalysis. A series of regional climatic simulations (for the period 19912010) for the Euro-CORDEX domain were conducted including ARI and ARI + ACI (ARCI), establishing as a reference a simulation where aerosols were not included interactively (BASE).

The results show that the effects of ARI and ACI on timemean spatially averaged precipitation over the whole domain are limited. However, a spatial redistribution of precipitation occurs when the ARI and ACI processes are introduced into the model, as well do changes in the precipitation intensity regimes. The main differences with respect to the base-case simulations occur in central Europe, where a decrease in precipitation is associated with a depletion in the number of rainy days and clouds at low level (CLL). This reduction in precipitation presents a strong correlation with the ratio $\mathrm{PM}_{2.5} / \mathrm{PM}_{10}$, since the decrease is especially intense during those events with high values of that ratio (pointing to high levels of anthropogenic aerosols) over central Europe. The
\end{abstract}

precipitation decrease occurs for all ranges of precipitation rates. On the other hand, the model produces an increase in precipitation over the eastern Mediterranean basin associated with an increase in clouds and rainy days when ACIs are implemented. Here, the change is caused by the high presence of $\mathrm{PM}_{10}$ (low $\mathrm{PM}_{2.5} / \mathrm{PM}_{10}$ ratios, pointing to natural aerosols). In this case, the higher amount of precipitation affects only days with low rates of precipitation. Finally, there are some disperse areas where the inclusion of aerosols leads to an increase in precipitation, especially for moderate and high precipitation rates.

\section{Introduction}

The importance of atmospheric aerosols has multiple aspects, all of great scientific and socioeconomic relevance. First, the World Health Organization (WHO, 2013) has recognized that the degradation of air quality by atmospheric aerosols is a threat to human health. Second, the Fifth Assessment Report (AR5) of the Intergovernmental Panel on Climate Change (IPCC) points to atmospheric aerosols as one of the main sources of uncertainty in current climate simulations (Boucher et al., 2013). Myhre et al. (2013) indicate that the uncertainty in the radiative forcing produced by aerosols greatly exceeds that of all other forcing mechanisms combined.

Despite the increasing number of articles published on the interactions between aerosols and climate over the last 
20 years (Fuzzi et al., 2015), the uncertainty associated with the estimated radiative forcing attributed to the interactions between aerosols and clouds has not diminished during the last four cycles of the IPCC (Seinfeld et al., 2016). One of the main tools for estimating the impact of atmospheric aerosols on climate is the use of global and regional climate models (Boucher et al., 2013). However, many of the simulations attempting to reproduce both the present climate and future climatic scenarios, or the extreme events that occur in situations of present or future climates, do not take into account the role of aerosol-radiation and aerosol-cloud interactions (ARIs and ACIs, respectively, in the terminology of AR5).

In addition to their radiative effect, aerosols act as condensation nuclei for cloud formation and can therefore affect precipitation in several ways (Andreae and Rosenfeld, 2008; Rosenfeld et al., 2008). Rosenfeld et al. (2008) studied the role of aerosols in polluted and pristine atmospheres for tropical areas. In polluted atmospheres, as there is a larger amount of condensation nuclei for the same humidity, the cloud drops are smaller, and therefore aerosols hamper precipitation. The slower cloud-droplet-to-rain conversion allows the droplets to be transported above freezing level, and thus the latent heat released in freezing intensifies the convection. However, this has no general validity, since this behavior could change locally, depending on the area. Indeed, understanding and characterizing the role that aerosols play in the development of convective clouds is today a cutting-edge scientific challenge (Archer-Nicholls et al., 2016). Authors such as Seifert et al. (2012) and Fan et al. (2013) find a very weak effect on precipitation by introducing aerosol-cloud interactions. Da Silva et al. (2018) analyze the effects on microphysics for the year 2013 for the Euro-Mediterranean region and conclude that precipitation decreases when there is a higher amount of aerosols.

Better understanding of the ARI and ACI is therefore essential for identifying climate change and its manifestation through changes in the frequency and severity of precipitation events (Huang et al., 2007; Khain et al., 2008; Stevens and Feingold, 2009; Fuzzi et al., 2015). Along the same lines, works such as Shrivastava et al. (2013), Forkel et al. (2015), Turnock et al. (2015), Yahya et al. (2016), Palacios-Peãa et al. (2018), Palacios-Peña et al. (2019) and Pavlidis et al. (2020) highlight that it is necessary to use regional climatechemical coupled models to investigate ACIs in more detail. These studies cover mainly the continental US, Asia and Europe and investigate chemical and meteorological variables such as precipitation, temperature and radiation. As indicated by Seinfeld et al. (2016), improving the estimation of the aerosol impact on clouds and reducing associated uncertainty are critical challenges for climate modeling studies. Despite the errors and uncertainties related to the role of aerosols in the climate system (Jiménez-Guerrero et al., 2013), only a small number of scientific papers have considered the analysis of climatic events using simulations that include ARI and ACI, which may strongly condition the representation and definition of events associated with precipitation and cloudiness (Prein et al., 2015; Baró et al., 2018).

In regional climate models, representation of the radiative effect of aerosols (ARI) is traditionally established by a constant aerosol optical depth (AOD) value and a predetermined and abundant number of cloud condensation nuclei (CCN) (Forkel et al., 2015). Although the lack of CCN is hardly ever a limiting factor for cloud formation (this could perhaps happen in remote marine locations in very specific conditions), a low $\mathrm{CCN}$ value may result in clouds that precipitate more readily, which can reduce the cloud lifetime and therefore the average cloud fraction (Stevens and Feingold, 2009). To obtain a more realistic model, ARI and ACI, which require models in which meteorology-climatology, radiation, clouds and aerosol atmospheric chemistry are coupled in a fully interactive way, must be included in the simulation (Grell and Baklanov, 2011; Baklanov et al., 2014). Fully coupled climate-chemistry models (on-line) make it possible to explain the feedback mechanisms between simulated aerosol concentrations and meteorological variables.

In simulations including ARI, the number of $\mathrm{CCN}$ remains unchanged, but the concentration of aerosols and their impact on the radiative balance is dynamically modeled (Houghton et al., 2001; Andreae et al., 2005). A region with a high emission of black carbon will absorb more radiation and increase the temperature of that layer of the atmosphere, favoring the destruction of clouds. However, an area with emissions of clear natural aerosols (e.g., sea salt) will favor radiative cooling due to the scattering of radiation (Yu et al., 2006).

Also, a further refinement in the configuration of the model adds the aerosol-cloud interactions. In this case, on-line estimation of aerosol concentrations is conducted in each time step of the model (as in the previous case), but this dynamical estimation is used to both calculate the radiative budget (as in ARI) and to estimate CCN for cloud formation. This will affect the number of drops within the cloud as well as their size, modifying the cloud's optical properties and thus its radiative balance (Twomey, 1977), and whether they reach the critical size to precipitate or not (Rosenfeld et al., 2008).

Introducing ACIs adds a level of complexity that brings the model configuration closer to real processes. However, it has a great computational cost and can increase calculation times from 6- to 10-fold (López-Romero et al., 2016; PalaciosPeña et al., 2020). It is therefore reasonable that most of the studies carried out so far with regional models taking into account these interactions have been for episodical case studies (Yang et al., 2012; Brunner et al., 2015; Palacios-Peña et al., 2019), and only a very limited number of contributions cover climatic periods with a general analysis (e.g., Witha et al., 2019; Pavlidis et al., 2020).

Hence, in this work, the role of ARI and ACI in precipitation and cloudiness over Europe has been exhaustively explored. For this purpose, regional climate simulations (19912010) for the Euro-CORDEX (Jacob et al., 2014) domain were carried out with WRF-Chem in order to account for 
the influence of atmospheric aerosols on the aforementioned variables.

\section{Data and methods}

\subsection{Experimental setup}

Regional climate simulations were carried out using the WRF-Chem model (v.3.6.1), both uncoupled from chemistry (WRF stand-alone configuration; Skamarock et al., 2008) and including a full on-line coupling with atmospheric chemistry and pollutant transport (for including ARI and ACI processes) (Grell et al., 2005).

Three different experiments were performed in this contribution. The first, BASE, consists of prescribing AOD and CCN, excluding ARI and ACI. The second, ARI, includes only aerosol radiation interactions (direct and semidirect effects). The third, ARCI, includes both aerosol-radiation and aerosol-cloud interactions (direct, semidirect and indirect effects). In ARI and ARCI, aerosols are calculated on-line. These experiments allow the effects of the aerosols on clouds and precipitation from a climatic perspective to be disentangled.

In the BASE experiment, aerosols are not treated interactively but by using the default WRF configuration, which considers $250 \mathrm{CCN}$ per cubic centimeter and setting AOD to 0 . In the ARI experiment, aerosols are treated on-line and ARI processes are activated in the model (Fast et al., 2006), but $\mathrm{CCN}$ remain as in the stand-alone version. The ARCI experiment includes the aforementioned ARI and, in addition, permits aerosols to interact with the microphysics processes. The description of ARCI as implemented in the simulations can be found in Palacios-Peña et al. (2020), as can validation of the AOD fields. To summarize, ARCIs in WRF-Chem were implemented by linking the simulated cloud droplet number with the Lin microphysics scheme (Lin et al., 1983), turning it into a two-moment scheme. Therefore, the droplet number affects both the calculated droplet mean radius and the cloud optical depth (Chapman et al., 2009).

The spatial configuration consists of two unidirectionally nested domains (one-way nesting). The domains used are shown in Fig. 1. The inner domain is compliant with EuroCORDEX recommendations (Jacob et al., 2014). It covers Europe with a spatial resolution of $0.44^{\circ}$ in latitude and longitude $(\sim 50 \mathrm{~km})$. The outer domain has a spatial resolution of about $150 \mathrm{~km}$ and extends southward to a latitude of approximately $20^{\circ} \mathrm{N}$. The design of this domain aims to cover the most important dust emission areas of the Saharan desert (Goudie and Middleton, 2001; Middleton and Goudie, 2001; Rodríguez et al., 2001; Goudie and Middleton, 2006) that are introduced to the inner domain through boundary conditions (Palacios-Peña et al., 2019). Nudging was used for the outer domain so that the atmospheric dynamics did not significantly vary (Liu et al., 2012). In the vertical, 29 non-

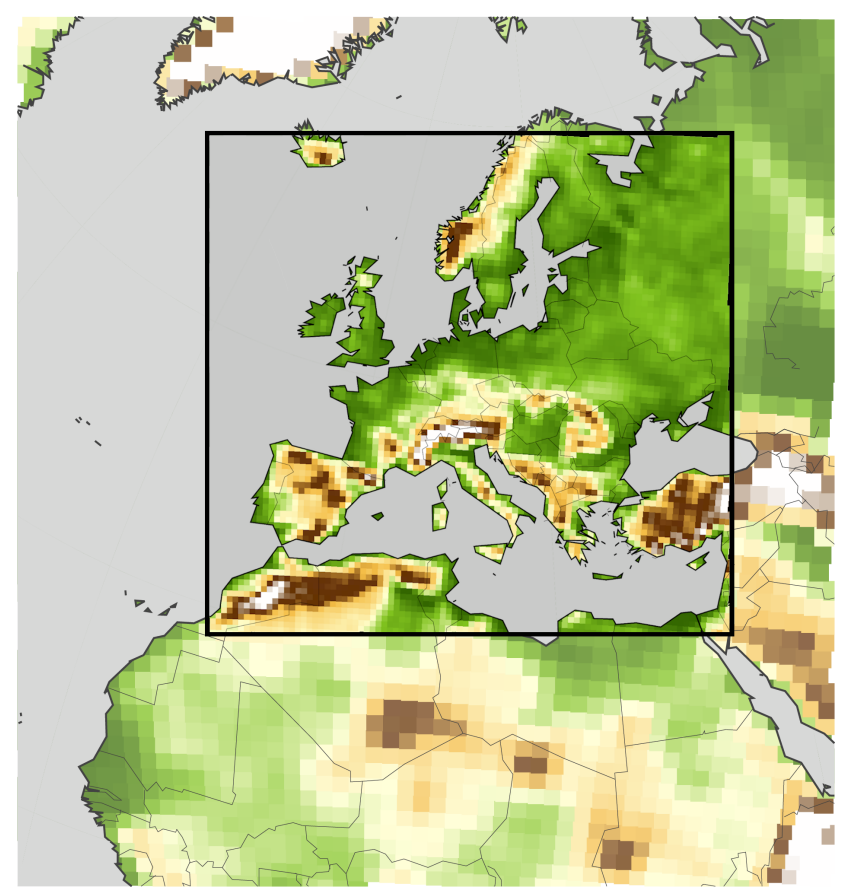

Figure 1. Simulation domains covered in the experiments. The inner Euro-CORDEX domain is boxed in the figure.

uniform sigma levels were used, with higher density levels near the surface. The upper limit was set at the $50 \mathrm{hPa}$ level.

The design of the physical configuration of the model was based on the compatibility with the chemical module and previous works (Baró et al., 2015; Palacios-Peña et al., 2016, 2017; Baró et al., 2017; Palacios-Peña et al., 2019). In addition to microphysics (Lin scheme), another important parameterization concerns radiation. The interactions of aerosol and clouds with incoming solar radiation were implemented by linking the simulated cloud droplet number with the RRTMG scheme and Lin microphysics (further details in Palacios-Peña et al., 2020). Therefore, the droplet number will affect both the calculated droplet mean radius and cloud optical depth. This should allow the dynamical treatment of aerosols and greenhouse gases in order to estimate the radiative budget. The RRTMG radiative scheme was used for both long- and shortwave (Iacono et al., 2008), while the Grell 3D scheme was used for the cumulus parameterization (Grell, 1993; Grell and Devenyi, 2002). The boundary layer was modeled with the Yonsei University scheme (Hong et al., 2006). The surface layer was parameterized using the Jiménez et al. (2012) scheme. Finally, the NOAH model (Tewari et al., 2004) was the land-soil model chosen to simulate the land-atmosphere interactions.

As mentioned above, aerosols are treated on-line; i.e., the model uses changing aerosols originating from anthropogenic emissions and generating natural aerosols throughout the interaction between atmospheric conditions and surface properties. Regarding the configuration and treatment 
of aerosols and gases, the gas-phase chemical mechanism RACM-KPP was used (Stockwell et al., 2001; Geiger et al., 2003) coupled to the GOCART aerosol scheme (Ginoux et al., 2001a; Chin et al., 2002). The photolysis module FastJ (Wild et al., 2000) was used to feed photochemical reactions. Biogenic emissions were calculated on-line using the Model of Emissions of Gases and Aerosols from Nature model (MEGAN) (Guenther et al., 2006). Dust and marine spray were simulated with GOCART (Ginoux et al., 2001b; Chin et al., 2002). Simulated aerosols included five species: sulfate, mineral dust, sea salt, organic matter and black carbon. Anthropogenic emissions were taken from the Intercomparison Project of Atmospheric and Climate Chemistry Models (Lamarque et al., 2013) and remained unchanged during the simulation period (monthly values for 2010). The ability of this configuration to represent the aerosol optical depth has been already extensively evaluated in PalaciosPeña et al. (2020). More details about the treatment of aerosols and their interactions can be found in Jerez et al. (2020b). The mean fields of these aerosols as well as the AOD are presented as a Supplement (Figs. S1-S5).

The simulated historical period for the three simulations covers the 2 decades from 1991 to 2010 . The boundary and initial conditions were extracted from the ECMWF reanalysis ERA20C (ECMWF, 2014; Hersbach et al., 2015), which has a horizontal resolution of approximately $125 \mathrm{~km}$ (T159). The simulations were run splitting the full period into subperiods of 5 years with a spin-up period of 4 months and then beginning with the direct interpolation of the soil data of the reanalysis. After removing the spin-up period, which was chosen in accordance with the results of Jerez et al. (2020a), the model outputs were merged. This methodology was tested in Jerez et al. (2020a). The boundary conditions for the outer domain were updated every $6 \mathrm{~h}$ and the model outputs recorded every hour. The observed evolution of greenhouse gases $\mathrm{CO}_{2}, \mathrm{CH}_{4}$ and $\mathrm{N}_{2} \mathrm{O}$ was incorporated as recommended in Jerez et al. (2018), varying $\mathrm{CO}_{2}$ between 353 and 390 over the simulated period.

\subsection{Methods}

This contribution focuses on the impacts of ARI and ACI on precipitation. Hence, the climatologies for precipitation amount, number of days with precipitation over a given threshold and cloudiness of the different experiments were intercompared for the BASE, ARI and ARCI simulations. The ERA5 (Hrarsbach and Dee, 2016) reanalysis data were used to calculate the added value of the aerosol experiments, since they have already been validated for precipitation (Albergel et al., 2018; Christensen et al., 2019; Hwang et al., 2019). Also represented are the comparison of the annual and seasonal climatologies for other atmospheric fields such as sea level pressure (slp), geopotential height $(Z)$ and temperature $(T)$ at 1000, 750 and $500 \mathrm{mb}$, maximum and minimum temperatures (tasmax, tasmin), daily temperature range (dtr), and solar radiation at surface (rsds) as well as mean temporal fields of the particulate matter $\left(\mathrm{PM}_{10}, \mathrm{PM}_{2.5}\right), \mathrm{BC}$ (black carbon) and AOD. All these fields are presented as a Supplement.

The statistical significance of the differences between the climatologies reproduced by the simulations was checked using a bootstrap method with 1000 repetitions and applying a $p$ value $<0.05$. Further details of this method can be found in Milelli et al. (2010).

In order to assess the relationship between the obtained changes in precipitation and different variables representing the aerosol load $\mathrm{PM}_{10}$ (particulate matter $<10 \mu \mathrm{m}$ ), $\mathrm{PM}_{2.5}$ (particulate matter $<2.5 \mu \mathrm{m}$ ), AOD at $550 \mathrm{~nm}$, and the ratio between $\mathrm{PM}_{2.5}$ and $\mathrm{PM}_{10}$ (hereinafter called $\mathrm{PM}_{\text {ratio }}$ ), several events (days) are grouped according to their intensity and extension. The intensity of an event is defined as the minimum value given by a threshold variable that the simulation cells must meet; the extension of an event is defined as the number of cells meeting the previous condition.

The relative differences (ARCI-BASE)/BASEx100 between the experiments are shown on a two-dimensional heat map, where the axes denote extent and intensity. The number of days on which the criteria defined above are met is indicated inside each element of the matrix. The total number of days analyzed is 7305 , corresponding to the 20 years simulated. This type of graph allows us to identify whether there is a relationship between the different variables and the magnitude of the change and to establish the relative importance of each factor involved. In the intervals where a relationship appears, a multiple linear regression fit was made, giving the multiple correlation coefficient as an indicator of the skill of the relationship.

On the other hand, the effect of aerosols could depend on the area and affect weak and strong precipitation events differently (Rosenfeld et al., 2008). The series of relative differences between the ARCI-BASE simulations were generated for common and non-common days with rainfall exceeding a certain threshold for all points in the domain. The threshold ranges from 0 to $20 \mathrm{~mm} \mathrm{~d}^{-1}$ on a non-linear scale (with a higher density of values near 0 ) with a total of 41 values. In order to investigate areas where the effect of aerosols on precipitation could be different, a clustering method was applied to the constructed series. The algorithm used for the spatial classification is similar to that used in other works (Jiménez et al., 2008; Lorente-Plazas et al., 2015) and is composed of several steps. First, an analysis of the principal components (Von Storch, 1999) is made and applied to the correlation matrix of the constructed series. Second, a two-step clustering method is applied to a number of the retained principal components. A hierarchical method is applied as a previous step; in this case, Ward's algorithm (Ward, 1963). This classification provides the number of clusters and initial seeds (also called centroids) for the final step, application of the nonhierarchical method $\mathrm{K}$ means which optimizes the grouping (Hartigan and Wong, 1979). Further details about the algo- 
rithm can be found in Lorente-Plazas et al. (2015). Finally, the mean regional series are calculated as the average of series belonging to a cluster (which corresponds to a spatial region in this study).

\section{Results and discussion}

\subsection{Precipitation differences in ARI and ARCI simulations}

The sensitivity of precipitation to the aerosol treatment in climate simulations is analyzed by comparing BASE, ARI and ARCI simulations over Europe over a 20 -year period. The differences between ARCI-BASE (ARI-BASE) in spatially averaged total precipitation are limited, around $0.5 \%$ $(0.1 \%)$. Figure 2 shows the relative differences with respect to BASE in the mean annual rainfall. The results depict a large spatial variability with differences ranging from $10 \%$ to $-10 \%$. Two zones with opposite behaviors are identified: (1) the central and eastern part of Europe, with a precipitation decrease of up to $8 \%$ (statistically significant, $p<0.05$ ), and (2) the eastern Mediterranean area, with increases of up to $10 \%$ (although the changes are not significant, $p>0.05$ ). Other areas, such as the Iberian Peninsula, present a strong spatial variability (e.g., rainfall increasing over the Mediterranean coast and decreasing over northeastern areas). Overall, the fact of introducing ARI and ACI leads to a redistribution of the annual precipitation. The most remarkable difference is a reduction in annual precipitation over central Europe for ARI, which is enhanced when the more intense and spatially extended ACIs are included. This reduction in precipitation is linked mainly to a reduction in the number of days with precipitation $>0.1 \mathrm{~mm}\left(N_{\mathrm{p} 01}\right)$ and clouds at low level (CLL); indeed, the most significant and widespread changes are obtained for CLL. Moreover, a statistically significant increase in $N_{\mathrm{p} 01}$ appears over the eastern Mediterranean but in this case only in ARCI experiments linked to an increase in CLL. At seasonal scale (see Supplement, Figs. S6-S11, for further information), the decrease in precipitation, CLL and $N_{\mathrm{p} 01}$ in central Europe is reproduced in all seasons but summer. In addition, the increase in the eastern Mediterranean is reproduced throughout the year, with the largest absolute changes in winter.

These changes are also related to others in several variables: for instance, rsds decreases in ARI and ARCI experiments mainly over the southern half of the domain, due to the higher AOD. However, there are some parts of central Europe where rsds rises due to the decrease in clouds, especially in autumn and spring (Figs. S12 and S13). Changes in temperature are different for tasmax and tasmin (Figs. S14 and S15). They are larger for tasmax, especially in ARCI, reaching differences around $0.5 \mathrm{~K}$ and presenting quite similar spatial patterns to those of CLL, while tasmin does not present any correlation with CLL. The most remarkable changes are obtained for dtr with a pattern characterized by an important increase in the north (lower CLL) and a decrease in the south (higher AOD) (Fig. S16). The modification of energy fluxes also affects circulation. The SLP fields, as well as $Z$ at several levels, also show statistically significant sensitivity to ARI and ACI effects (Figs. S17-S19). Here, the most remarkable features are the large differences between the ARI and ARCI experiments. ARCI shows a noticeable increase in slp in the central and northern parts of the domain with respect to ACI. This behavior is also appreciated for $Z$. Finally, it is worth highlighting that ARI and ARCI also indicate a rise in temperature over northern and central Europe. This might imply that simulated changes in precipitation can also be indirectly affected by changes in atmospheric circulation. This fact could make it more difficult to establish the relationship between changes in precipitation and changes in the treatment of aerosols in our experiments.

In order to investigate the variations in the regimes of precipitation, the changes in the number of rainy days are estimated. Figure 2 (and Fig. S9) shows the relative differences in the number of days with precipitation $>0.1 \mathrm{~mm}$. The patterns of differences are similar to those of averaged precipitation, implying that the reduction in precipitation is mainly caused by the decrease in the number of rainy days. However, there are some noticeable exceptions. The relationships in the two large areas mentioned above are direct; that is, higher rainfall is linked to a larger number of precipitation episodes. However, there are areas where the relationship is inverse, a higher (lower) number of days implies less (more) precipitation. Analysis of the low clouds in the domain (Figs. 2, S10 and S11) shows a pattern similar to the aforementioned ones. This might indicate that the effects of both ARI and ACI can play very different roles in cloud properties and therefore in precipitation, depending on the target area. This issue will be addressed later in this contribution.

\subsection{Evaluation against ERA5 reanalysis}

The added value of incorporating on-line aerosol interactions and complex aerosol physics into the model was calculated by analyzing the differences in precipitation, number of rainy days and low clouds between the simulations and the reanalysis of the European center ERA5 (Fig. 4). Overall, WRFChem (in both the BASE and ARCI simulations) tends to underestimate precipitation over the European Mediterranean region and along the coasts of the Nordic countries, while it overestimates rainfall in the rest of the domain. These patterns are analogous for all the variables analyzed. Looking only at the areas where the differences are significant, the ARCI simulations slightly reduce the differences in the spatial distribution. However, the differences between ERA5 and ARCI are much larger than the differences between ARCI and BASE.

Despite this, as previously noted (Fig. 2), the ARCI experiment introduces significant differences with respect to 


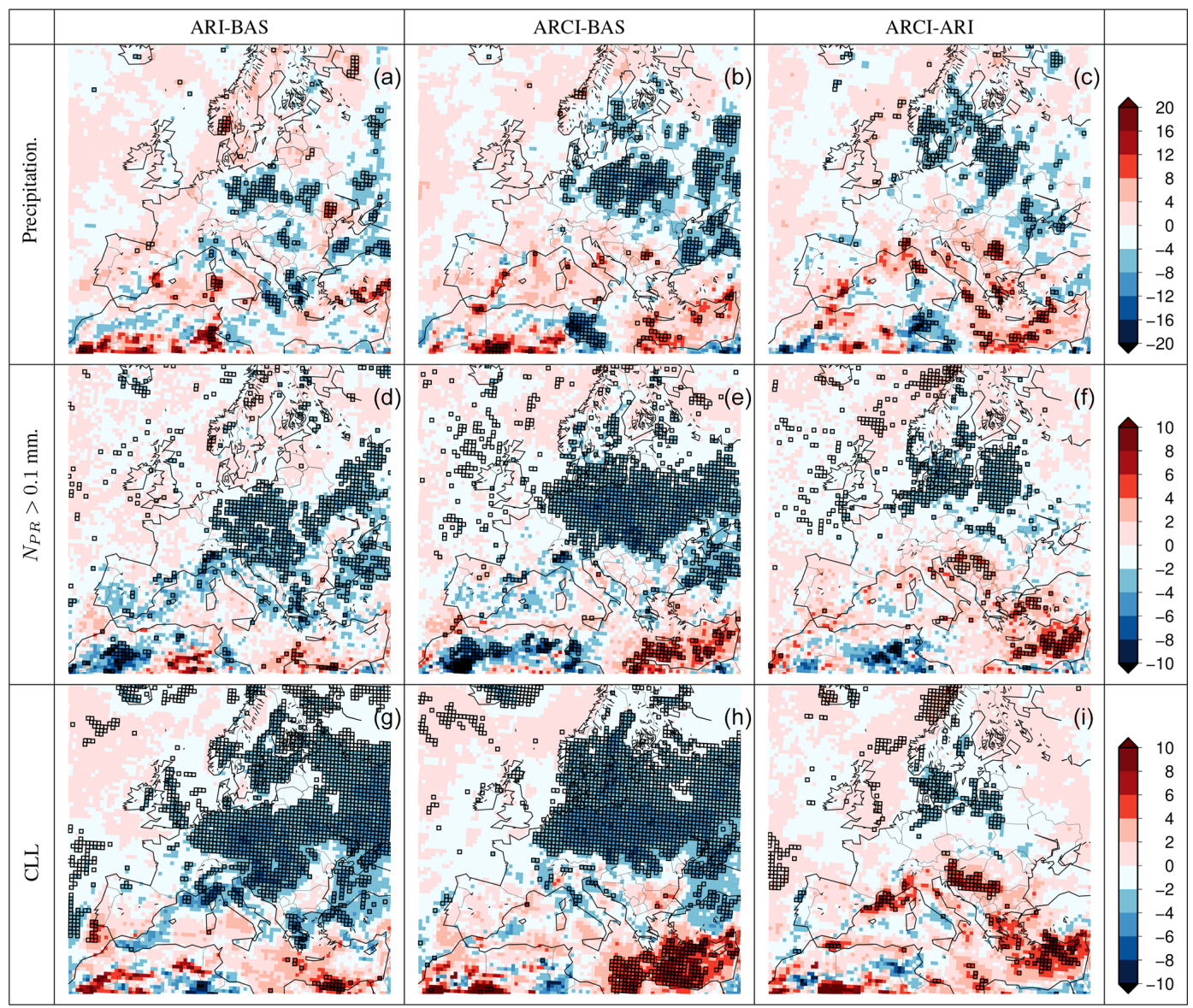

Figure 2. Relative differences for precipitation between ARI and BASE (a, d, g), ARCI and BASE (b, e, h), and ARCI and ARI (c, f, i), total precipitation $(\mathbf{a}-\mathbf{c})$ number of days of precipitation $>0.1 \mathrm{~mm}(\mathbf{d}-\mathbf{f})$, and low clouds $(\mathbf{g}-\mathbf{i})$. Squares indicate points whose differences are significant for a $p$ value of 0.05 . The analysis was conducted for the mean values of the period 1991-2010.

the BASE simulation over central Europe. These differences reach values of about $5 \%$ in the number of rainy days. A relationship between aerosols in these areas and the aforementioned changes might therefore be expected in spite of the induced changes in the dynamics. This relationship is explored in the following section of this contribution.

\subsection{Relationship between aerosol physical properties and precipitation}

In order to understand the contribution to changes in precipitation of the different types of aerosol, the differences in rainfall were assessed by choosing a set of episodes. These were selected according to the value of variables representative of the size and concentration $\left(\mathrm{PM}_{10}\right.$ and $\left.\mathrm{PM}_{2.5}\right)$, ratio $\left(\mathrm{PM}_{\text {ratio }}\right)$ and impacts on radiation (AOD) of the aerosols, as well as the spatial extension of the event.

Figure 5 shows the relative changes for the different sets of episodes for AOD at $550 \mathrm{~nm}$ (AOD550) (Fig. 5b), $\mathrm{PM}_{10}$ (Fig. 5d), $\mathrm{PM}_{2.5}$ (Fig. 5c) and the $\mathrm{PM}_{\text {ratio }}$ (Fig. 5d). The calculations were conducted using only the points with significant differences (Fig. 2). Figure 5a shows the relative changes (ARCI-BASE) in the number of rainy days for different sets of episodes, selected by choosing the extension or size of the episode (number of grid points) of the cells exceeding a value of $\mathrm{PM}_{\text {ratio }}$ (values from 0.2 to 0.8 ). In a range of intensities, quasi-linear relationships appear. Figure 5b-e show these relationships for the different variables.

The lower left box of Fig. 5e indicates that 5970 out of $7303 \mathrm{~d}$ present a $\mathrm{PM}_{\text {ratio }}>0.64$ ( $y$ axis) achieved in more than 180 cells of the domain ( $x$ axis). When calculating the differences in ARCI-BASE precipitation in the $5970 \mathrm{~d}$ meeting that condition $\left(\mathrm{PM}_{\text {ratio }}>0.64\right.$ in more than 180 cells of the domain), the differences in rainy days over those cells is around $4 \%$. Thus, e.g., the number of days in which $\mathrm{PM}_{\text {ratio }}$ is $>0.75$ in more than 280 points is 1030 and the reduction in the number of rainy days is $8 \%$. Following with $\mathrm{PM}_{\text {ratio }}$ (Fig. 5e), the higher the intensity, the larger the reduction in the number of rainy days; and the greater the extent or size of the event, the larger the reduction in rainy days (e.g., reaching the maximum reduction around $15 \%$ ). 


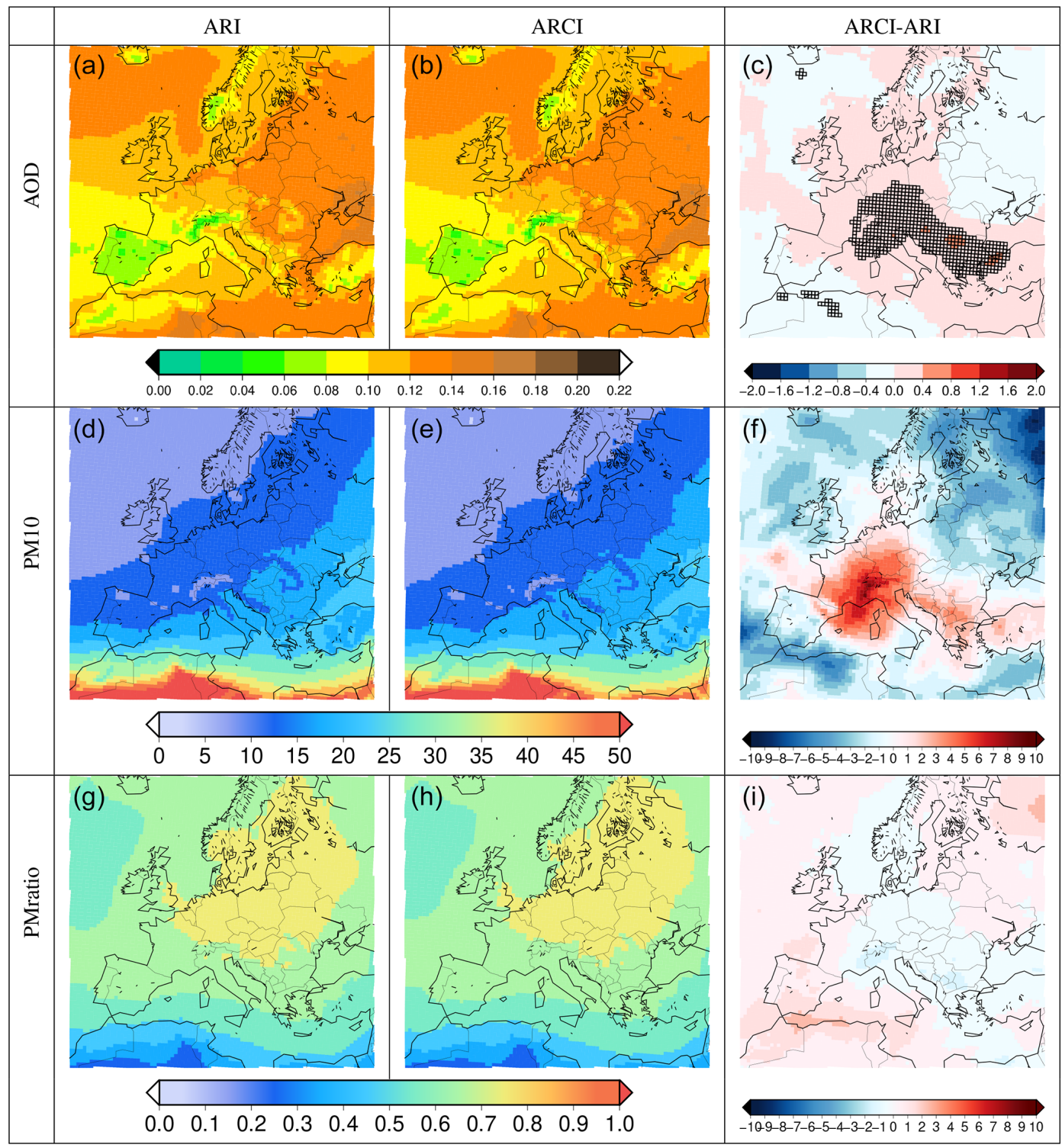

Figure 3. $\mathrm{AOD}, \mathrm{PM}_{10}\left(\mu \mathrm{g} \mathrm{m}^{-3}\right)$ and $\mathrm{PM}_{\text {ratio }}$ mean annual values for $\mathrm{ARI}$ and $\mathrm{ARCI}$ and their differences $(\%)$.

Indeed, the multiple regression coefficient between the different variables is $R=0.80$.

For AOD550 (Fig. 5b), the results show that higher AOD550 values lead to a lower reduction in the number of rainy days. The changes are small (under $2 \%$ ) although the relationship is clear $(R=0.78)$. The results are analogous for $\mathrm{PM}_{2.5}$ (Fig. 5c), but the relationship is less clear $(R=0.53)$. For $\mathrm{PM}_{10}$, the changes are higher but with a less clear relationship $(R=0.40)$. However, the relationships with the $\mathrm{PM}_{\text {ratio }}$ (Fig. 5e) are important and significant $(R=0.80)$. Therefore, an important conclusion is that the variable with the largest impact on the number of rainy days is the $\mathrm{PM}_{\text {ratio }}$ in that area.

The possible physical explanation for this behavior in this area is that the higher the $\mathrm{PM}_{\text {ratio }}$ (Fig. 3), the higher the con- centration of small particles changing the properties of the clouds (mainly low clouds) (Fig. 2; a reduction in low cloudiness over central Europe) and leading to a clearer atmosphere. This results in higher temperatures and an increase in the condensation level, leading to a reduction in the number of rainy days and therefore a decrease in the amount of precipitation (direct and semidirect effects). As noted in Fig. 2, the reduction in CLL also occurs in the ARI experiment. This could be explained by the atmospheric warming caused by the radiation absorption of dark atmospheric aerosols (black carbon), causing the above effect. The stronger signal in ARCI can be attributed to the addition of both processes. On the other hand, a high concentration episode of $\mathrm{PM}_{2.5}$ can occur together with a $\mathrm{PM}_{10}$ event, decreasing the $\mathrm{PM}_{\text {ratio }}$. Therefore, the better relationship with $\mathrm{PM}_{\text {ratio }}$ could be re- 

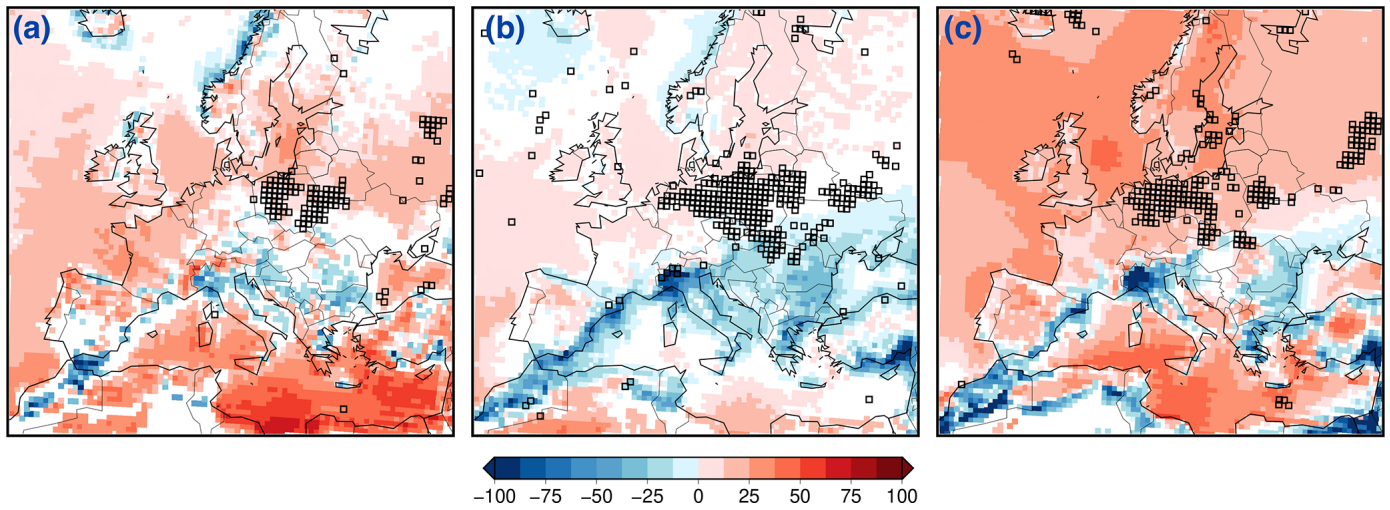

Figure 4. Significant relative differences (colors) between ARCI and ERA5 for (a) precipitation, (b) number of days of precipitation $>0.1 \mathrm{~mm}$ and (c) clouds at low levels. Squares indicate statistically significant differences $(p<0.05)$. The analysis was conducted for the mean values of the period 1991-2010.

lated to coarse aerosols enhancing precipitation and thereby counteracting the effect of smaller aerosols.

\subsection{Regional role of aerosols in precipitation}

As noted previously, the relationships between changes in precipitation, number of rainy days and cloudiness are different in different regions of our domain. Therefore, the role of aerosols, analyzed considering either their nature or their concentration, causes different changes in precipitation regimes. In order to quantify this effect, the series of relative changes in the number of rainy days were constructed at each point for different thresholds ranging from 0.1 to $20 \mathrm{~mm} \mathrm{~d}^{-1}$. The grouping method described in the methodology section was applied to this series, obtaining five different regions (Fig. 6). The clusters are listed according to the number of grid cells of each group, with Cluster 1 the most numerous and also the most dispersed. The centroid series (average series of regions) are represented in Fig. 7. The (green) filled circles indicate that the relative differences between the ARCI and BASE experiments are significant.

Cluster 1 does not present a clear pattern, covering most of the points of the Atlantic Ocean and southern Europe. This area has very low, non-significant differences, with values between $0.5 \%$ and $-2.5 \%$. Therefore, the effect of including aerosol-cloud interactions in this area does not practically affect precipitation. Clusters 2 and 5 have a similar behavior. In both zones, there is a decrease in precipitation for almost all thresholds except the most extreme rainfall events where precipitation increases. In Cluster 2, the changes range from $-2 \%$ to $-4 \%$, with significant differences for low thresholds (up to $2 \mathrm{~mm} \mathrm{~d}^{-1}$ ). In the case of Cluster 5, the differences are always significant and much larger. The maximum reduction is obtained for episodes of precipitation above $14 \mathrm{~mm} \mathrm{~d}^{-1}$, reaching relative changes in the precipitation of the entire area of around $12 \%$. Note that
Cluster 5 almost coincides with the area previously analyzed (significant differences, Fig. 2).

Clusters 3 and 4 have a different behavior. In these regions, an increase in precipitation occurs when including ARCI. Cluster 3 does not have a clear spatial pattern, with points scattered along the entire domain. For low thresholds, there are no significant changes; for high thresholds, there is a very significant increase in precipitation with significant relative changes (e.g., $5 \%$ for a threshold of $8 \mathrm{~mm} \mathrm{~d}^{-1}$ ). For higher thresholds, the relative changes are close to $20 \%$. However, this result should be analyzed with caution because of the lack of spatial structure, although from the statistical point of view there is a coherent increase in moderate and intense precipitation events that can be explained by some physical processes presented in the literature (Khain et al., 2008).

Finally, Cluster 4 shows a clear spatial pattern, with most of the points concentrated in the eastern Mediterranean. Over this area, the range of thresholds between 1 and $5 \mathrm{~mm} \mathrm{~d}^{-1}$ presents significant differences, while for thresholds $>5 \mathrm{~mm} \mathrm{~d}^{-1}$, the series remain constant around $4.5 \%$ and the statistical significance disappears.

Therefore, the role of the aerosols in precipitations shows a clear spatial dependence, affecting strong and weak precipitation differently. Over regions 2 and 5, which cover northern, central and eastern Europe, ARI and ACI tend to reduce precipitation. This reduction is significant for almost all events below $15 \mathrm{~mm} \mathrm{~d}^{-1}$. In the Mediterranean area, and especially in the eastern Mediterranean, rainfall increases in the ARCI experiment, mainly due to the increase in the number of days with rainfall below $5 \mathrm{~mm} \mathrm{~d}^{-1}$. Meanwhile, in Cluster 3 , the total rainfall undergoes very variable changes but fundamentally an increase in moderate and strong rainfall events. 
(a) NDP $>0.1 \mathrm{~mm}$ for PMratio events

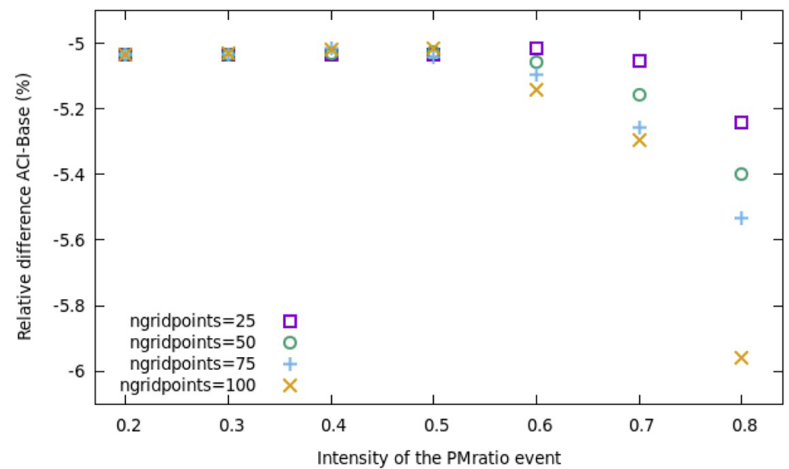

(b) NDP $>0.1 \mathrm{~mm}$ for AOD550 events. $R=0.78$.

(c) NDP $>0.1 \mathrm{~mm}$ for $\mathrm{PM} 2.5$ events. $\mathrm{R}=0.53$.
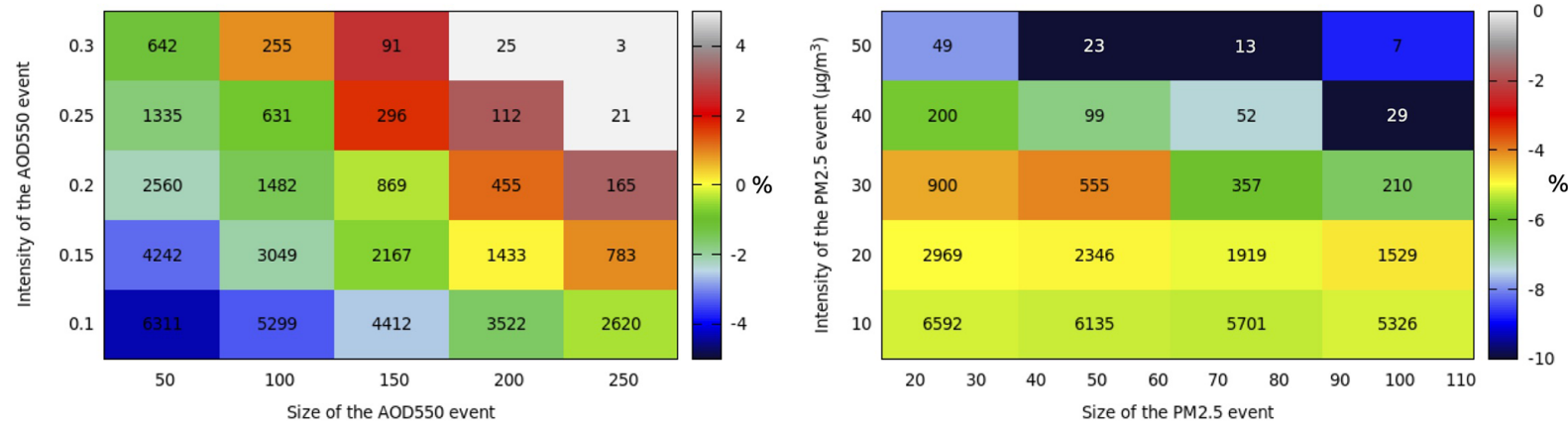

(d) NDP $>0.1 \mathrm{~mm}$ for PM10 events. $R=0.40$.

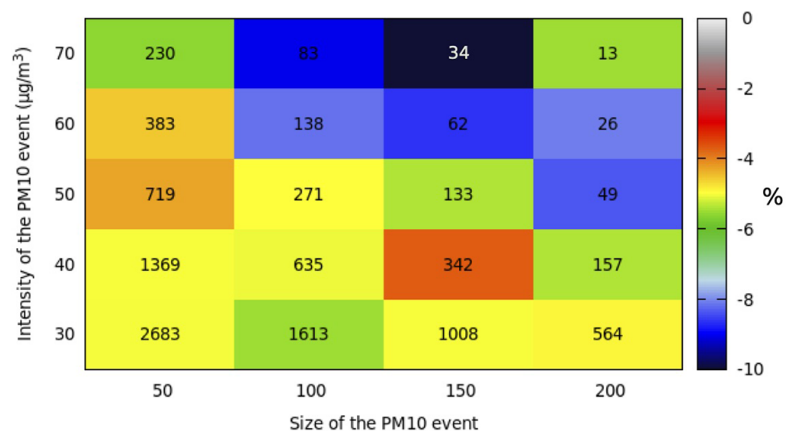

(e) NDP $>0.1 \mathrm{~mm}$ for PMratio events. $R=0.80$.

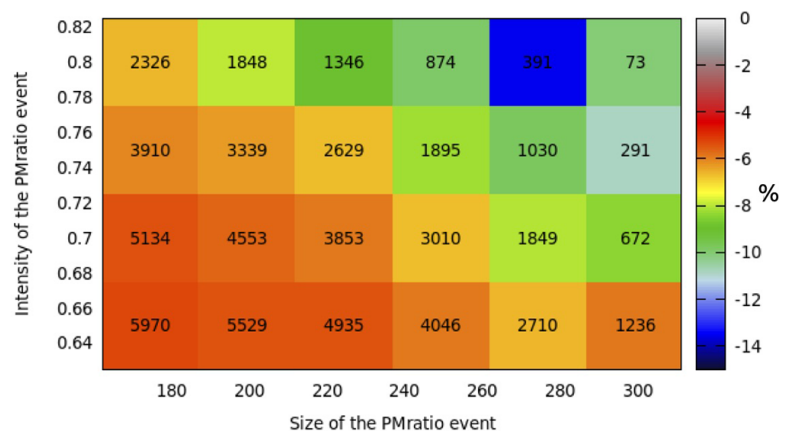

Figure 5. Relative difference (colors) in the ARCI-BASE simulations for the 1991-2010 period based on (b) the intensity and size of AOD550 events, (c) the intensity and size of $\mathrm{PM}_{2.5}$ events, (d) for events of $\mathrm{PM}_{10}$, and (e) for those of $\mathrm{PM}_{\text {ratio. }}$ The calculation is made for the domain cells with significant ARCI-BASE differences for the number of days with precipitation $>0.1 \mathrm{~mm}$ (Fig. $2 \mathrm{~b}$ ) and only for the zone where the non-linear behavior begins $(>0.6)$ in (a) (identical to the other variables). The number inside the boxes indicates the number of days meeting the corresponding criteria of intensity and extent of events. $R$ denotes the multiple regression coefficient resulting from a multi-linear adjustment of those values.

\subsection{ARI vs. ARCI relevance for modifying precipitation}

In order to better understand the processes involved in each of the areas, the absolute annual values and differences between ARCI and ARI are analyzed in terms of the concentrations of $\mathrm{PM}_{10}, \mathrm{PM}_{2.5}$ and $\mathrm{PM}_{\text {ratio }}$ (Fig. 3). This will allow us to discriminate which processes (aerosol-radiation or aerosol-cloud interactions) are most relevant. As commented above, Fig. 2 shows the differences in ARCI-BASE, ARI-
BASE and ARCI-ARI analyzing precipitation (number of days exceeding $0.1 \mathrm{~mm} \mathrm{~d}^{-1}$ and total amount) and the cloud cover at low level. In the case of Cluster 5, both simulations provide a reduction in the number of days of precipitation. Therefore, both ARI and ACI affect precipitation in the same direction. ARI causes an increase in temperature at low levels (see temperature at $850 \mathrm{hPa}$, Fig. S21), especially in autumn and spring, leading to a reduction in clouds and precipitation. A possible explanation would be that the ARCI experiment 


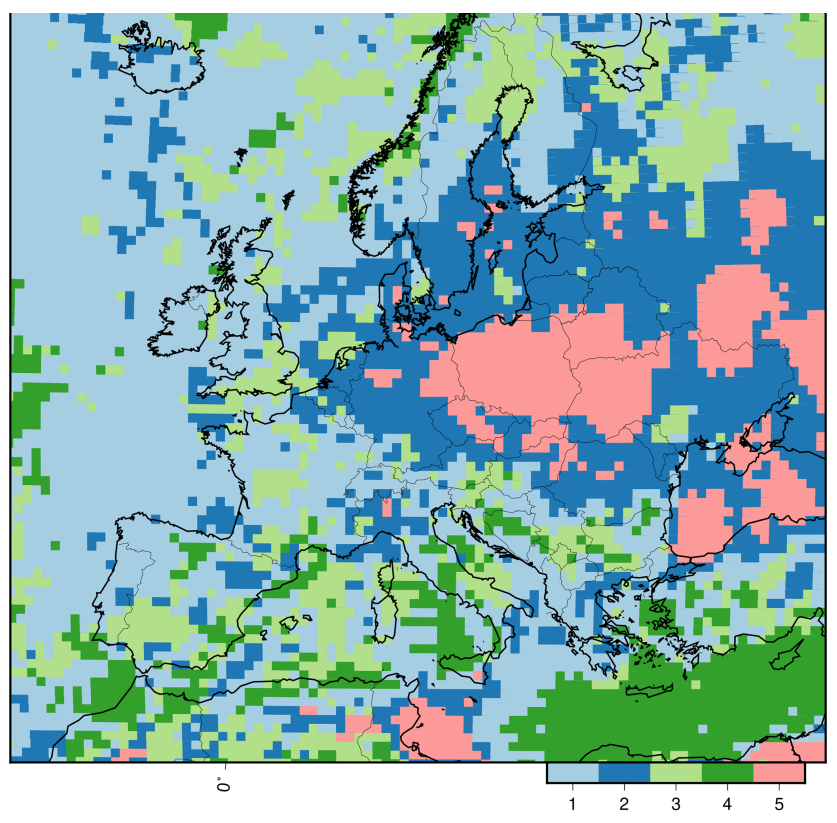

Figure 6. Cluster analysis of rainy days: each color depicts a cluster with different behavior of the ARCI-BASE difference in number of days of precipitation over a threshold running from $0.1 \mathrm{~mm}$ to $20 \mathrm{~mm} \mathrm{~d}^{-1}$ for the period 1991-2010.

enhances this effect by the higher concentration of small particles modifying the properties of the clouds, inhibiting precipitation processes again by reducing clouds due to microphysical processes, since over this area there is a prevalence of small aerosols (see PM $\mathrm{PM}_{\text {ratio }}$ in Figs. 3 and S1-S5). Another possible explanation could be linked to the changes in circulation which reduce both cloudiness and precipitation (see Fig. S17-S22).

Finally, the increase in precipitation and cloudiness in Cluster 4 could be associated with larger values of $\mathrm{PM}_{10}$ (large condensation nuclei). In this case, the ARI effects are almost negligible during the year. However, the ARCI experiment shows a clear positive difference with respect to the BASE case and ARI. Figure 8 shows the relative difference in the concentration of $\mathrm{PM}_{10}$ between ARCI and ARI and the differences in the number of rainy days with precipitation $>1 \mathrm{~mm} \mathrm{~d}^{-1}$. The points are distributed in a quasirandom way with respect to 0 . The cells of the whole of Cluster 4 show a bias towards positive values for changes in precipitation and a decrease for $\mathrm{PM}_{10}$. Focusing only on the eastern Mediterranean of Cluster 4 (yellow points), the relationship is clear. Most of the points showing an increase in precipitation undergo a decrease in $\mathrm{PM}_{10}$. A plausible explanation is that in these areas the $\mathrm{PM}_{10}$ load is high due to the intrusion of desert dust and sea-salt aerosols. The difference between the ARCI and ARI simulations is the activation of the aerosol-cloud interaction mechanism, using the aerosols calculated on-line as $\mathrm{CCN}$ to form clouds, while in ARI, the $\mathrm{CCN}$ are prescribed at a fixed value. The $\mathrm{PM}_{10}$ used to form clouds in ARCI will no longer be counted in $\mathrm{PM}_{10}$ because of in-cloud scavenging. Therefore, a decrease in $\mathrm{PM}_{10}$ occurs, and this coincides with an increase in cloudiness. In addition, the increase in precipitation will also decrease $\mathrm{PM}_{10}$ due to wet deposition. Note that the patterns do not completely coincide, with the precipitation pattern shifted slightly to the north (see the comparison in Fig. 2). This can be attributed to the displacement of the cloud masses in such an area. This behavior can be attributed to the role of giant aerosol particles in warm rain initiation (Johnson, 1982), increasing stratiform precipitation by dust through deposition growth (Gong et al., 2010) or enhanced drizzle formation in stratocumulus (Feingold et al., 1999).

\section{Conclusions}

The effect of atmospheric aerosols on regional climate simulations nowadays presents many uncertainties due to complex and non-linear processes which depend on a wide variety of factors. The quantity, size and optical properties of aerosols condition the modification of the radiative budget and, therefore, many other derived variables such as local temperature, cloudiness or precipitation. In addition, the amount of available moisture determines the size of the water droplets based on the amount and type of aerosols available. Atmospheric aerosols also affect the size and optical properties of the clouds, which also modify the radiative budget. Moreover, these processes can spatially redistribute the precipitation regimes, allowing rainfall in different areas or provoking changes in its intensity. Despite the importance of the problem from a climatological point of view, there is a scarcity of scientific contributions that have studied these issues. The large increase in the computational time needed to include ACI and ARI in regional climate simulations has traditionally hampered the work covering this analysis from a climatic perspective.

In order to address the aforementioned issues, a set of regional climate simulations was conducted for the period 1991-2010 without on-line aerosol-atmosphere interactions (BASE), with ARI and with ARI + ACI (ARCI) parameterizations in an on-line coupled model. All the simulations cover the domain of Europe defined by the EuroCORDEX initiative. This analysis focused on average precipitation, number of precipitation days over a certain threshold and cloudiness. In addition, the effects on other variables such as temperature at different levels, geopotential height, radiation at surface and sea level pressure are presented as a Supplement.

When introducing the ACI and ARI, the spatial average of the total rainfall does not differ from the BASE scenario. However, there is a spatial redistribution of such precipitation. Although there are changes in several places throughout the domain, the largest modification occurs in central Europe, where a decrease in precipitation is found as a result of acti- 
(a) Cluster 5

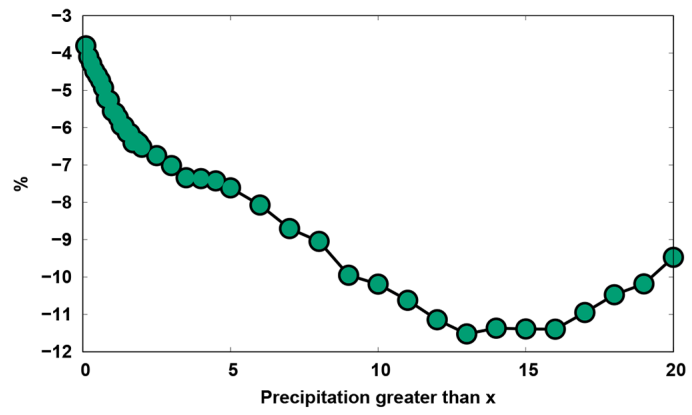

(b) Cluster 1

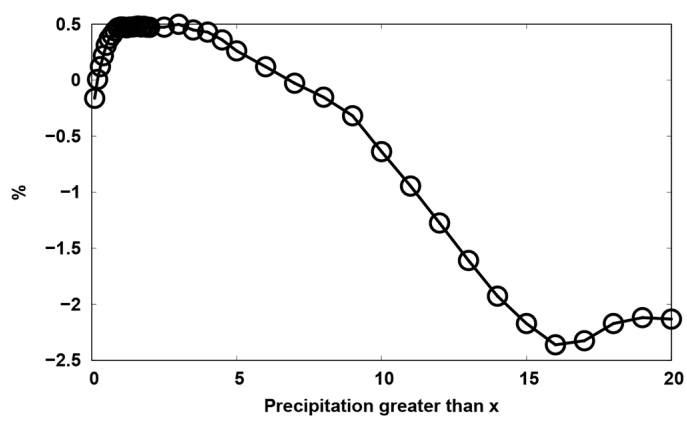

(d) Cluster 3

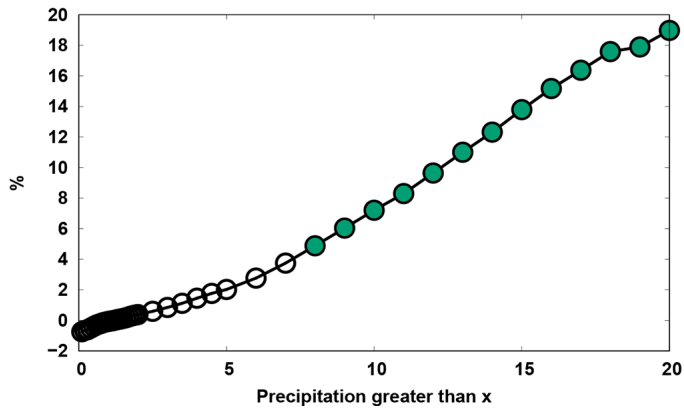

(c) Cluster 2

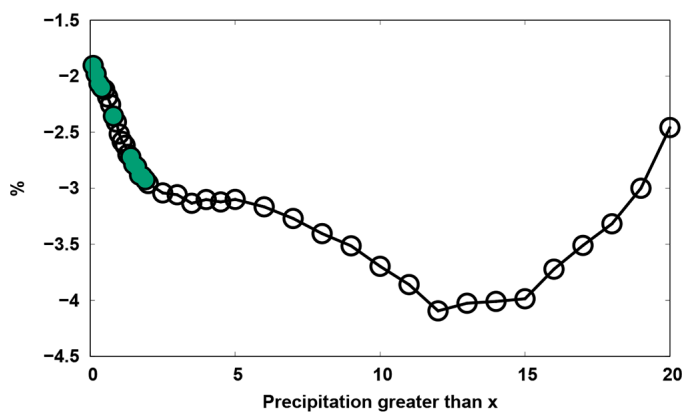

(e) Cluster 4

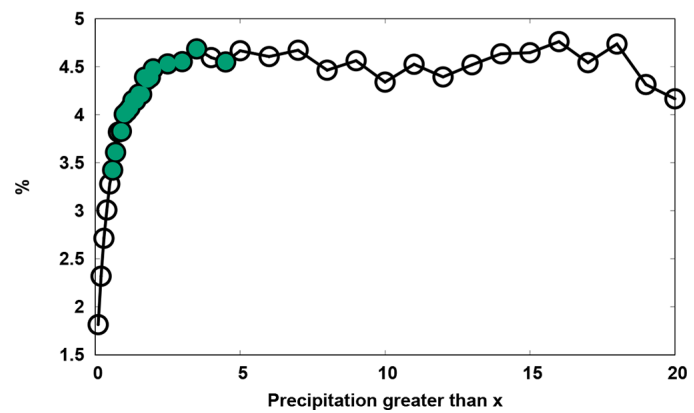

Figure 7. Series of relative differences between ARCI and BASE based on different thresholds in rainy days for the different regions (Fig. 6). Green circles denote the thresholds for which the differences are significant ( $p$ value $<0.05$ ).

vating the aerosol-radiation and aerosol-cloud interactions. The behavior is the opposite in the eastern Mediterranean, where the effects of aerosol-cloud interactions prevail. These results are reproduced by analyzing the number of days of precipitation $>0.1 \mathrm{~mm}$, with very similar patterns. However, there are areas where the relationship between precipitation and the number of rainy days is not straightforward.

When the results are compared with ERA5, the BASE simulation tends to overestimate rainfall across the domain except in some areas of Mediterranean and Nordic countries. When the ACIs are incorporated into the modeling setup, these differences are reduced, although quantitatively this improvement is limited.

The results obtained for the number of precipitation days $>0.1 \mathrm{~mm}$ were related to different aerosol variables (AOD550, $\mathrm{PM}_{2.5}, \mathrm{PM}_{10}$ and $\mathrm{PM}_{\text {ratio}}$ ). That relationship shows a highly non-linear behavior, although a regime where the linear approximation is acceptable was also identified. For central Europe, in the linear regime, the intensity and extension (size) of the $\mathrm{PM}_{\text {ratio }}$ events have a direct relationship with the increase in the differences in the number of rainy days.

Although the previous conclusion is limited to the number of days of precipitation $>0.1 \mathrm{~mm}$, it becomes interesting to check the relationship for other thresholds. Five types of behavior throughout the target domain were identified by analyzing several precipitation thresholds. Aerosols contribute positively or negatively to precipitation depending on the area and the intensity of precipitation. The available humidity, efficiency of the $\mathrm{CCN}$ and type of aerosol (size, optical properties, shape) are the most important factors conditioning the type of behavior. In the experiments 


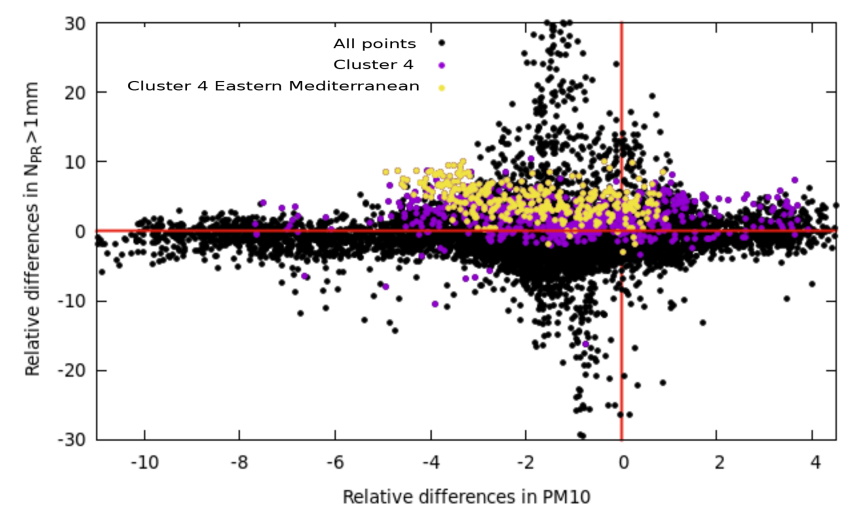

Figure 8. Relative differences (ARCI-BASE) of the number of days of precipitation $>1 \mathrm{~mm}$ vs. $\mathrm{PM}_{10}$ (ARCI) for all the cells of the domain (black), for Cluster 4 (violet) and Cluster 4 but only in the Mediterranean (yellow).

conducted, the inclusion of ARCI leads to a reduction in precipitation in all regimes in northern-central and eastern parts of Europe. However, in the eastern Mediterranean, precipitation increases due to the increase in days with rainfall $<5 \mathrm{~mm} \mathrm{~d}^{-1}$. Positive changes for moderate and strong rainfall regimes are also found over some areas (Cluster 3, which is a very dispersed area). Although this finding can be identified with the so-called deepening effect (Stevens and Feingold, 2009), relating aerosols to an increase in precipitation for some convective events, this statement should be considered with caution because of the lack of spatial structure of this cluster. The rest of the areas are barely affected.

Some of the changes obtained can be related to the direct, semidirect and indirect effects of aerosols on clouds. The reduction in precipitation over some areas could be linked to both atmosphere warming and excess of CCN. The radiative processes have the ability to change the thermodynamic environment due to the absorption of radiation by fine dark particles (mainly black carbon), stabilizing the environment or increasing the condensation level. The excess of CCN leads to small drops producing a depletion in precipitation. In principle, this would increase the lifetime effect; however, the experiments presented here show an extra depletion of cloudiness, possibly related to faster evaporation of the water drops. All these processes are associated with a high concentration of fine aerosols with respect to coarse particles. On the other hand, the effects of coarse aerosols ( $\mathrm{PM}_{10}$, giant condensation nuclei) seem to be the complete opposite. These particles seem to enhance precipitation processes, especially increasing light precipitation events (Feingold et al., 1999) or accelerating precipitation development. Sometimes both processes (semidirect and indirect) overlap, with a negligible net effect.

In conclusion, the effect of aerosols on climatic variables is varied and complex and further studies on this topic are needed in order to (1) reduce the uncertainty associated with the inclusion of aerosols in regional climate experiments and (2) better understand the physical and microphysical processes leading to changes in precipitation. This contribution demonstrates from a modeling approach that changes in the concentration, extension and type of aerosols alter the precipitation regimes and amount in different ways. These changes are spatially and seasonally dependent and in agreement with other works (e.g., Li et al., 2019). The inclusion in regional climate experiments of on-line aerosols, as well as cloudaerosol interactions, alter precipitation patterns as well as other surface and upper air variables (Pavlidis et al., 2020; Jerez et al., 2020b) and could differ from other approximations such as using AOD climatologies or prescribed CCN (Nabat et al., 2015). It would be interesting to see to which extent other regional models would reproduce the current results for the Euro-CORDEX region in order to analyze the possible model dependence of the results. Future research aimed at disentangling the effects of aerosols on regional climate simulations should be devoted to understanding the role of regional and large-scale circulation (regimes), possible feedbacks, and overlapping processes.

Data availability. All data employed (monthly means) in this study are available at https://doi.org/10.5281/zenodo.4427810 (Montávez, 2021). Data at higher temporal resolution are available upon request to montavez@um.es.

Supplement. The supplement related to this article is available online at: https://doi.org/10.5194/acp-21-415-2021-supplement.

Author contributions. JMLR, JPM and PJG designed the research. JMLR performed the experiments. JMLR, JPM, SJ and RLP analyzed the outputs from experiments. LPP contributed to the design of the numerical experiments, and JMLR and JPM wrote the paper, with input from all coauthors.

Competing interests. The authors declare that they have no conflict of interest.

Acknowledgements. The authors thank the WRF-Chem development community and the G-MAR research group at the University of Murcia for the fruitful scientific discussions.

Financial support. This research was funded by the European Regional Development Fund - Fondo Europeo de Desarrollo Regional (ERDF-FEDER), the Spanish Ministry of Economy and Competitiveness (MINECO), the Spanish Ministry of Science and Innovation (MICINN), the Agencia Estatal de Investigación (AEI) through the projects EASE (grant number RTI2018100870-A-I00, MICINN/AEI/FEDER-ERDF) and ACEX (grant number CGL2017-87921-R, MINECO/AEI/FEDER-ERDF). Also, 
the Seneca Foundation - Agency for Science and Technology in the Region of Murcia funded the CLIMAX project (20642/JLI/18). Laura Palacios-Peña is grateful for the FPU14/05505 scholarship and to the Spanish Ministry of Education, Culture and Sports. José María López-Romero acknowledges the FPI-BES2015-074062 grant from the Spanish Ministry of Science.

Review statement. This paper was edited by Ari Laaksonen and reviewed by two anonymous referees.

\section{References}

Albergel, C., Dutra, E., Munier, S., Calvet, J.-C., Munoz-Sabater, J., de Rosnay, P., and Balsamo, G.: ERA-5 and ERA-Interim driven ISBA land surface model simulations: which one performs better?, Hydrol. Earth Syst. Sci., 22, 3515-3532, https://doi.org/10.5194/hess-22-3515-2018, 2018.

Andreae, M. and Rosenfeld, D.: Aerosol-cloud-precipitation interactions. Part 1. The nature and sources of cloud-active aerosols, Earth-Sci. Rev., 89, 13-41, 2008.

Andreae, M. O., Jones, C. D., and Cox, P. M.: Strong presentday aerosol cooling implies a hot future, Nature, 435, 1187, https://doi.org/10.1038/nature03671, 2005.

Archer-Nicholls, S., Lowe, D., Schultz, D. M., and McFiggans, G.: Aerosol-radiation-cloud interactions in a regional coupled model: the effects of convective parameterisation and resolution, Atmos. Chem. Phys., 16, 5573-5594, https://doi.org/10.5194/acp-16-5573-2016, 2016.

Baklanov, A., Schlünzen, K., Suppan, P., Baldasano, J., Brunner, D., Aksoyoglu, S., Carmichael, G., Douros, J., Flemming, J., Forkel, R., Galmarini, S., Gauss, M., Grell, G., Hirtl, M., Joffre, S., Jorba, O., Kaas, E., Kaasik, M., Kallos, G., Kong, X., Korsholm, U., Kurganskiy, A., Kushta, J., Lohmann, U., Mahura, A., Manders-Groot, A., Maurizi, A., Moussiopoulos, N., Rao, S. T., Savage, N., Seigneur, C., Sokhi, R. S., Solazzo, E., Solomos, S., Sørensen, B., Tsegas, G., Vignati, E., Vogel, B., and Zhang, Y.: Online coupled regional meteorology chemistry models in Europe: current status and prospects, Atmos. Chem. Phys., 14, 317-398, https://doi.org/10.5194/acp-14-317-2014, 2014.

Baró, R., Jiménez-Guerrero, P., Balzarini, A., Curci, G., Forkel, R., Grell, G., Hirtl, M., Honzak, L., Langer, M., Pérez, J. L., Pirovano, G., San José, R., Tuccella, P., Werhahn, J., and Žabkar, R.: Sensitivity analysis of the microphysics scheme in WRFChem contributions to AQMEII phase 2, Atmos. Environ., 115, 620-629, 2015.

Baró, R., Lorente-Plazas, R., Montávez, J. P., and JiménezGuerrero, P.: Biomass burning aerosol impact on surface winds during the 2010 Russian heat wave, Geophys. Res. Lett., 44, 1088-1094, https://doi.org/10.1002/2016GL071484, 2017.

Baró, R., Jiménez-Guerrero, P., Stengel, M., Brunner, D., Curci, G., Forkel, R., Nea, L., Palacios-Peña, L., Savage, N., Schaap, M., Tuccella, P., van der Gon, H. D., and Galmarini, S.: Evaluating cloud properties in an ensemble of regional online coupled models against satellite observations, Atmos. Chem. Phys., 18, 15183-15199, https://doi.org/10.5194/acp-18-15183-2018, 2018.
Boucher, O., Randall, D., Artaxo, P., Bretherton, C., Feingold, G., Forster, P., Kerminen, V.-M., Kondo, Y., Liao, H., Lohmann, U., Rasch, P., Satheesh, S. K., Sherwood, S., Stevens, B., and Zhang, X. Y.: Clouds and Aerosols in Climate Change 2013: The Physical Science Basis, in: Contribution of Working Group I to IPCC AR5, edited by: Stocker, T. F., Qin, D., Plattner, G.-K., Tignor, M., Allen, S. K., Boschung, J., Nauels, A., Xia, Y., Bex, V., and Midgley, P. M., Cambridge University Press, Cambridge, UK and New York, NY, USA, 2013.

Brunner, D., Savage, N., Jorba, O., Eder, B., Giordano, L., Badia, A., Balzarini, A., Baró, R., Bianconi, R., Chemel, C., Curci, G., Forkel, R., Jiménez-Guerrero, P., Hirtl, M., Hodzic, A., Honzak, L., Im, U., Knote, C., Makar, P., Manders-Groot, A., van Meijgaard, E., Neal, L., Pérez, J. L., Pirovano, G., Jose, R. S., Schröder, W., Sokhi, R. S., Syrakov, D., Torian, A., Tuccella, P., Werhahn, J., Wolke, R., Yahya, K., Zabkar, R., Zhang, Y., Hogrefe, C., and Galmarini, S.: Comparative analysis of meteorological performance of coupled chemistry-meteorology models in the context of AQMEII phase 2, Atmos. Environ., 115, 470-498, https://doi.org/10.1016/j.atmosenv.2014.12.032, 2015.

Chapman, E. G., Gustafson Jr., W. I., Easter, R. C., Barnard, J. C., Ghan, S. J., Pekour, M. S., and Fast, J. D.: Coupling aerosol-cloud-radiative processes in the WRF-Chem model: Investigating the radiative impact of elevated point sources, Atmos. Chem. Phys., 9, 945-964, https://doi.org/10.5194/acp-9945-2009, 2009

Chin, M., Ginoux, P., Kinne, S., Torres, O., Holben, B. N., Duncan, B. N., Martin, R. V., Logan, J. A., Higurashi, A., and Nakajima, T.: Tropospheric aerosol optical thickness from the GOCART model and comparisons with satellite and Sun photometer measurements, J. Atmos. Sci., 59, 461-483, 2002.

Christensen, M. F., Heaton, M. J., Rupper, S., Reese, C. S., and Christensen, W. F.: Bayesian Multi-scale Spatio-temporal Modeling of Precipitation in the Indus Watershed, Front. Earth Sci., 7, 210, https://doi.org/10.3389/feart.2019.00210, 2019.

Da Silva, N., Mailler, S., and Drobinski, P.: Aerosol indirect effects on summer precipitation in a regional climate model for the Euro-Mediterranean region, Ann. Geophys., 36, 321-335, https://doi.org/10.5194/angeo-36-321-2018, 2018.

ECMWF: ERA-20C, available at: https://www.ecmwf.int/en/ forecasts/datasets/reanalysis-datasets/era-20c (last access: 3 March 2020), 2014.

Fan, J., Leung, L. R., Rosenfeld, D., Chen, Q., Li, Z., Zhang, J., and Yan, H.: Microphysical effects determine macrophysical response for aerosol impacts on deep convective clouds, P. Natl. Acad. Sci. USA, 110, E4581-E4590, 2013.

Fast, J., Gustafson Jr., W., Easter, R., Zaveri, R., Barnard, J., Chapman, E., Grell, G., and Peckham, S.: Evolution of ozone, particulates, and aerosol direct forcing in an urban area using a new fully-coupled meteorology, chemistry, and aerosol model, J. Geophys. Res, 111, D21305, https://doi.org/10.1029/2005JD006721, 2006.

Feingold, G., Cotton, W. R., Kreidenweis, S. M., and Davis, J. T.: The Impact of Giant Cloud Condensation Nuclei on Drizzle Formation in Stratocumulus: Implications for Cloud Radiative Properties, J. Atmos. Sci., 56, 4100-4117, https://doi.org/10.1175/15200469(1999)056<4100:TIOGCC>2.0.CO;2, 1999. 
Forkel, R., Balzarini, A., Baró, R., Bianconi, R., Curci, G., JiménezGuerrero, P., Hirtl, M., Honzak, L., Lorenz, C., Im, U., Pérez, J. L., Pirovano, G., José, R. S., Tuccella, P., Werhahn, J., and Žabkar, R.: Analysis of the WRF-Chem contributions to AQMEII phase2 with respect to aerosol radiative feedbacks on meteorology and pollutant distributions, Atmos. Environ., 115, 630-645, 2015.

Fuzzi, S., Baltensperger, U., Carslaw, K., Decesari, S., Denier van der Gon, H., Facchini, M. C., Fowler, D., Koren, I., Langford, B., Lohmann, U., Nemitz, E., Pandis, S., Riipinen, I., Rudich, Y., Schaap, M., Slowik, J. G., Spracklen, D. V., Vignati, E., Wild, M., Williams, M., and Gilardoni, S.: Particulate matter, air quality and climate: lessons learned and future needs, Atmos. Chem. Phys., 15, 8217-8299, https://doi.org/10.5194/acp15-8217-2015, 2015.

Geiger, H., Barnes, I., Bejan, I., Benter, T., and Spittler, M.: The tropospheric degradation of isoprene: an updated module for the regional atmospheric chemistry mechanism, Atmos. Environ., 37, 1503-1519, https://doi.org/10.1016/S1352-2310(02)01047$6,2003$.

Ginoux, P., Chin, M., Tegen, I., Prospero, J. M., Holben, B., Dubovik, O., and Lin, S.-J.: Sources and distributions of dust aerosols simulated with the GOCART model, J. Geophys. Res.-Atmos., 106, 20255-20273, https://doi.org/10.1029/2000JD000053, 2001a.

Ginoux, P., Chin, M., Tegen, I., Prospero, J. M., Holben, B., Dubovik, O., and Lin, S.-J.: Sources and distributions of dust aerosols simulated with the GOCART model, J. Geophys. Res.Atmos., 106, 20255-20273, 2001b.

Gong, W., Min, Q., Li, R., Teller, A., Joseph, E., and Morris, V.: Detailed cloud resolving model simulations of the impacts of Saharan air layer dust on tropical deep convection - Part 1: Dust acts as ice nuclei, Atmos. Chem. Phys. Discuss., 10, 12907-12952, https://doi.org/10.5194/acpd-10-12907-2010, 2010.

Goudie, A. and Middleton, N.: Saharan dust storms: nature and consequences, Earth-Sci. Rev., 56, 179-204, 2001.

Goudie, A. S. and Middleton, N. J.: Desert dust in the global system, Springer Science \& Business Media, Heidelberg, Germany, 2006.

Grell, G. and Baklanov, A.: Integrated modeling for forecasting weather and air quality: A call for fully coupled approaches, Atmos. Environ., 45, 6845-6851, 2011.

Grell, G. A.: Prognostic Evaluation of Assumptions Used by Cumulus Parameterizations, Mon. Weather Rev., 121, 764-787, 1993.

Grell, G. A. and Devenyi, D.: A generalized approach to parameterizing convection combining ensemble and data assimilation techniques, Geophys. Res. Lett., 29, 1693, https://doi.org/10.1029/2002GL015311, 2002.

Grell, G. A., Peckham, S. E., Schmitz, R., McKeen, S. A., Frost, G., Skamarock, W. C., and Eder, B.: Fully coupled "online" chemistry within the WRF model, Atmos. Environ., 39, 6957-6975, 2005.

Guenther, A., Karl, T., Harley, P., Wiedinmyer, C., Palmer, P. I., and Geron, C.: Estimates of global terrestrial isoprene emissions using MEGAN (Model of Emissions of Gases and Aerosols from Nature), Atmos. Chem. Phys., 6, 3181-3210, https://doi.org/10.5194/acp-6-3181-2006, 2006.

Hartigan, J. A. and Wong, M. A.: Algorithm AS 136: A k-means clustering algorithm, J. Roy. Stat. Soc. Ser. C, 28, 100-108, 1979.
Hersbach, H., Peubey, C., Simmons, A., Berrisford, P., Poli, P., and Dee, D.: ERA-20CM: a twentieth-century atmospheric model ensemble, Q. J. Roy. Meteorol. Soc., 141, 2350-2375, 2015.

Hong, S.-Y., Noh, Y., and Dudhia, J.: A new vertical diffusion package with an explicit treatment of entrainment processes, Mon. Weather Rev., 134, 2318-2341, 2006.

Houghton, J. T., Ding, Y., Griggs, D. J., Noguer, M., van der Linden, P. J., Dai, X., Maskell, K., and Johnson, C.: Climate change 2001: the scientific basis, The Press Syndicate of the University of Cambridge, Cambridge, 2001.

Hrarsbach, H. and Dee, D.: ERA5 reanalysis is in production, ECMWF Newslett., 147, 5-6, 2016.

Huang, Y., Chameides, W. L., and Dickinson, R. E.: Direct and indirect effects of anthropogenic aerosols on regional precipitation over east Asia, J. Geophys. Res.-Atmos., 112, D03212, https://doi.org/10.1029/2006JD007114, 2007.

Hwang, S.-O., Park, J., and Kim, H. M.: Effect of hydrometeor species on very-short-range simulations of precipitation using ERA5, Atmos. Res., 218, 245-256, 2019.

Iacono, M. J., Delamere, J. S., Mlawer, E. J., Shephard, M. W., Clough, S. A., and Collins, W. D.: Radiative forcing by long-lived greenhouse gases: Calculations with the AER radiative transfer models, J. Geophys. Res., 113, D13103, https://doi.org/10.1029/2008JD009944, 2008.

Jacob, D., Petersen, J., Eggert, B., Alias, A., Christensen, O. B., Bouwer, L. M., Braun, A., Colette, A., Déqué, M., Georgievski, G., Georgopoulou, E., Gobiet, A., Menut, L., Nikulin, G., Haensler, A., Hempelamnn, N., Jones, C., Leuler, K., Kovats, S., Kröner, N., Kotlarski, S., Kriegsmann, A., Martin, E., van Meijgaard, E., Moseley, C., Pfeifer, S., Preuschmann, S., Radermacher, C., Radtke, K., Rechi, D., Rounsevell, M., Samuel, P., Somot, S., Soussana, J.-F., Teichmann, C., Valentini, R., Vautard, R., Weber, B., and Yiou, P.: EURO-CORDEX: new highresolution climate change projections for European impact research, Reg. Environ. Change, 14, 563-578, 2014.

Jerez, S., López-Romero, J., Turco, M., Jiménez-Guerrero, P., Vautard, R., and Montávez, J.: Impact of evolving greenhouse gas forcing on the warming signal in regional climate model experiments, Nat. Commun., 9, 1304, https://doi.org/10.1038/s41467018-03527-y, 2018.

Jerez, S., López-Romero, J. M., Turco, M., Lorente-Plazas, R., Gómez-Navarro, J. J., Jiménez-Guerrero, P., and Montávez, J. P.: On the spin-up period in WRF simulations over Europe: trade offs between length and seasonality, J. Adv. Model. Earth Syst., 12, e2019MS001945, https://doi.org/10.1029/2019MS001945, 2020a.

Jerez, S., Palacios-Peña, L., Gutiérrez, C., Jiménez-Guerrero, P., López-Romero, J. M., and Montávez, J. P.: Gains and losses in surface solar radiation with dynamic aerosols in regional climate simulations for Europe, Geosci. Model Dev. Discuss., https://doi.org/10.5194/gmd-2020-238, in review, 2020b.

Jiménez, P., García-Bustamante, E., González-Rouco, J., Valero, F., Montávez, J., and Navarro, J.: Surface wind regionalization in complex terrain, J. Appl. Meteorol. Clim., 47, 308-325, 2008.

Jiménez, P. A., Dudhia, J., González-Rouco, J. F., Navarro, J., Montávez, J. P., and García-Bustamante, E.: A revised scheme for the WRF surface layer formulation, Mon. Weather Rev., 140, 898918, 2012. 
Jiménez-Guerrero, P., Jerez, S., Montávez, J., and Trigo, R.: Uncertainties in future ozone and $\mathrm{PM}_{10}$ projections over Europe from a regional climate multiphysics ensemble, Geophys. Res. Lett., 40, 5764-5769, 2013.

Johnson, D. B.: The Role of Giant and Ultragiant Aerosol Particles in Warm Rain Initiation, J. Atmos. Sci., 39, 448-460, 1982.

Khain, A., BenMoshe, N., and Pokrovsky, A.: Factors determining the impact of aerosols on surface precipitation from clouds: An attempt at classification, J. Atmos. Sci., 65, 1721-1748, 2008.

Lamarque, J. F., Shindell, D. T., Josse, B., Young, P. J., Cionni, I., Eyring, V., Bergmann, D., Cameron-Smith, P., Collins, W. J., Doherty, R., Dalsoren, S., Faluvegi, G., Folberth, G., Ghan, S. J., Horowitz, L. W., Lee, Y. H., MacKenzie, I. A., Nagashima, T., Naik, V., Plummer, D., Righi, M., Rumbold, S. T., Schulz, M., Skeie, R. B., Stevenson, D. S., Strode, S., Sudo, K., Szopa, S., Voulgarakis, A., and Zeng, G.: The Atmospheric Chemistry and Climate Model Intercomparison Project (ACCMIP): overview and description of models, simulations and climate diagnostics, Geosci. Model Dev., 6, 179-206, https://doi.org/10.5194/gmd-6179-2013, 2013.

Li, Z., Wang, Y., Guo, J., Zhao, C., Cribb, M. C., Dong, X., Fan, J., Gong, D., Huang, J., Jiang, M., Jiang, Y., Lee, S.-S., Li, H., Li, J., Liu, J., Qian, Y., Rosenfeld, D., Shan, S., Sun, Y., Wang, H., Xin, J., Yan, X., Yang, X., Yang, X.-Q., Zhang, F., and Zheng, Y.: East Asian Study of Tropospheric Aerosols and their Impact on Regional Clouds, Precipitation, and Climate (EAST-AIRCPC), J. Geophys. Res.-Atmos., 124, 1302613054, https://doi.org/10.1029/2019JD030758, 2019.

Lin, Y.-L., Farley, R. D., and Orville, H. D.: Parameterization of the Snow Field in a Cloud Model, J. Clim. Appl. Meteorol., 22, 1065-1092, 1983.

Liu, P., Tsimpidi, A. P., Hu, Y., Stone, B., Russell, A. G., and Nenes, A.: Differences between downscaling with spectral and grid nudging using WRF, Atmos. Chem. Phys., 12, 3601-3610, https://doi.org/10.5194/acp-12-3601-2012, 2012.

López-Romero, J. M., Baró, R., Palacios-Peña, L., Jerez, S., Jiménez-Guerrero, P., and Montávez, J. P.: Impact of resolution on aerosol radiative feedbacks with in online-coupled chemistry/climate simulations (WRF-Chem) for EURO-CORDEX compliant domains, in: vol. 18, EGU General Assembly Conference Abstracts, 17-22 April 2016, Vienna, Austria, 2016.

Lorente-Plazas, R., Montávez, J., Jimenez, P., Jerez, S., GómezNavarro, J., García-Valero, J., and Jimenez-Guerrero, P.: Characterization of surface winds over the Iberian Peninsula, Int. J. Climatol., 35, 1007-1026, 2015.

Middleton, N. and Goudie, A.: Saharan dust: sources and trajectories, T. Inst. Brit. Geogr., 26, 165-181, 2001

Milelli, M., Turco, M., and Oberto, E.: Screen-level non-GTS data assimilation in a limited-area mesoscale model, Nat. Hazards Earth Syst. Sci., 10, 1129-1149, https://doi.org/10.5194/nhess10-1129-2010, 2010.

Montávez, J. P.: Data set of monthly climate and aerosol variables included in https://doi.org/10.5194/acp-21-1-2021 (Version 1.0) [Data set]. Atmospheric Chemistry and Physics, Zenodo, https://doi.org/10.5281/zenodo.4427810, 2021.

Myhre, G., Shindell, D., Bréon, F.-M., Collins, W., Fuglestvedt, J., Huang, J., Koch, D., Lamarque, J.-F., Lee, D., Mendoza, B., Nakajima, T., Robock, A., Stephens, G., Takemura, T., and
Zhang, H.: Anthropogenic and natural radiative forcing, Climate Change, 423, 658-740, 2013.

Nabat, P., Somot, S., Mallet, M., Sevault, F., Chiacchio, M., and Wild, M.: Direct and semi-direct aerosol radiative effect on the Mediterranean climate variability using a coupled regional climate system model, Clim. Dynam., 44, 1127-1155, 2015.

Palacios-Peña, L., Baró, R., López-Romero, J. M., López-Villagra, A., Jerez, S., Montávez, J. P., and Jiménez-Guerrero, P.: Assessment of Aerosol-Radiation (ARI) and Aerosol-Cloud (ACI) Interactions from Dust: Modelled Dust Optical Properties and Remote Sensing Observations, in: International Technical Meeting on Air Pollution Modelling and its Application, Springer Nature Switzerland AG, 183-187, 2016.

Palacios-Peña, L., Baró, R., Guerrero-Rascado, J. L., AladosArboledas, L., Brunner, D., and Jiménez-Guerrero, P.: Evaluating the representation of aerosol optical properties using an online coupled model over the Iberian Peninsula, Atmos. Chem. Phys. 17, 277-296, https://doi.org/10.5194/acp-17-277-2017, 2017.

Palacios-Peña, L., Baró, R., Baklanov, A., Balzarini, A., Brunner, D., Forkel, R., Hirtl, M., Honzak, L., López-Romero, J. M., Montávez, J. P., Pérez, J. L., Pirovano, G., San José, R., Schroeder, W., Werhahn, J., Wolke, R., Zabkar, R., and Jiménez-Guerrero, P.: An assessment of aerosol optical properties from remotesensing observations and regional chemistry-climate coupled models over Europe, Atmos. Chem. Phys., 18, 5021-5043, https://doi.org/10.5194/acp-18-5021-2018, 2018.

Palacios-Peña, L., Jiménez-Guerrero, P., Baró, R., Balzarini, A., Bianconi, R., Curci, G., Landi, T. C., Pirovano, G., Prank, M., Riccio, A., Tuccella, P., and Galmarini, S.: Aerosol optical properties over Europe: an evaluation of the AQMEII Phase 3 simulations against satellite observations, Atmos. Chem. Phys., 19, 2965-2990, https://doi.org/10.5194/acp-19-2965-2019, 2019.

Palacios-Peña, L., Montávez, J. P., López-Romero, J. M., Jerez, S., Gómez-Navarro, J. J., Lorente-Plazas, R., Ruiz, J., and Jiménez-Guerrero, P.: Added Value of Aerosol-Cloud Interactions for Representing Aerosol Optical Depth in an Online Coupled Climate-Chemistry Model over Europe, Atmosphere, 11, 360, https://doi.org/10.3390/atmos11040360, 2020.

Pavlidis, V., Katragkou, E., Prein, A., Georgoulias, A. K., Kartsios, S., Zanis, P., and Karacostas, T.: Investigating the sensitivity to resolving aerosol interactions in downscaling regional model experiments with WRFv3.8.1 over Europe, Geosci. Model Dev., 13, 2511-2532, https://doi.org/10.5194/gmd-13-2511-2020, 2020.

Prein, A. F., Gobiet, A., Truhetz, H., Keuler, K., Görgen, K., Teichmann, C., Fox Maule, C., van Meijgaard, E., Déqué, M., Nikulin, G., Vautard, R., Colette, A., Kjellström, E., and Jacob, D.: Precipitation in the EURO-CORDEX and $0.44^{\circ}$ simulations: high resolution, high benefits?, Clim. Dynam., 46, 383-412, 2015.

Rodríguez, S., Querol, X., Alastuey, A., Kallos, G., and Kakaliagou, O.: Saharan dust contributions to $\mathrm{PM}_{10}$ and TSP levels in Southern and Eastern Spain, Atmos. Environ., 35, 2433-2447, 2001.

Rosenfeld, D., Lohmann, U., Raga, G. B., O’Dowd, C. D., Kulmala, M., Fuzzi, S., Reissell, A., and Andreae, M. O.: Flood or drought: how do aerosols affect precipitation?, Science, 321, 1309-1313, 2008.

Seifert, A., Köhler, C., and Beheng, K. D.: Aerosol-cloudprecipitation effects over Germany as simulated by a convectivescale numerical weather prediction model, Atmos. Chem. Phys., 12, 709-725, https://doi.org/10.5194/acp-12-709-2012, 2012. 
Seinfeld, J. H., Bretherton, C., Carslaw, K. S., Coe, H., DeMott, P. J., Dunlea, E. J., Feingold, G., Ghan, S., Guenther, A. B., Kahn, R., Kraucunas, I., Kreidenweis, S. M., Molina, M. J., Nenes, A., Penner, J. E., Prather, K. A., Ramanathan, V., Ramaswamy, V., Rasch, P. J., Ravishankara, A. R., Rosenfeld, D., Stephens, G., and Wood, R.: Improving our fundamental understanding of the role of aerosol-cloud interactions in the climate system, P. Natl. Acad. Sci. USA, 113, 5781-5790, https://doi.org/10.1073/pnas.1514043113, 2016.

Shrivastava, M., Berg, L. K., Fast, J. D., Easter, R. C., Laskin, A., Chapman, E. G., Gustafson Jr., W. I., Liu, Y., and Berkowitz, C. M.: Modeling aerosols and their interactions with shallow cumuli during the 2007 CHAPS field study, J. Geophys. Res.-Atmos., 118, 1343-1360, 2013.

Skamarock, W. C., Klemp, J. B., Dudhia, J., Gill, D. O., Barker, D. M., Wang, W., and Powers, J. G.: A description of the Advanced Research WRF version 3, Tech. rep., NCAR Tech. Note TN475+STR, National Center for Atmospheric Research, Boulder, https://doi.org/10.5065/D68S4MVH, 2008.

Stevens, B. and Feingold, G.: Untangling aerosol effects on clouds and precipitation in a buffered system, Nature, 461, 607-613, 2009.

Stockwell, W. R., Kirchner, F., Kuhn, M., and Seefeld, S.: A new mechanism for regional atmospheric chemistry modeling, J. Geophys. Res.-Atmos., 102, 25847-25879, https://doi.org/10.1029/97JD00849, 2001.

Tewari, M., Chen, F., Wang, W., Dudhia, J., LeMone, M. A., Mitchell, K., Ek, M., Gayno, G., Wegiel, J., and Cuenca, R. H.: Implementation and verification of the unified NOAH land surface model in the WRF model, in: 20th conference on weather analysis and forecasting/16th conference on numerical weather prediction, 14 January 2004, Seattle, WA, USA, 11-15, 2004.

Turnock, S. T., Spracklen, D. V., Carslaw, K. S., Mann, G. W., Woodhouse, M. T., Forster, P. M., Haywood, J., Johnson, C. E., Dalvi, M., Bellouin, N., and Sanchez-Lorenzo, A.: Modelled and observed changes in aerosols and surface solar radiation over $\mathrm{Eu}-$ rope between 1960 and 2009, Atmos. Chem. Phys., 15, 94779500, https://doi.org/10.5194/acp-15-9477-2015, 2015.

Twomey, S.: The influence of pollution on the shortwave albedo of clouds, J. Atmos. Sci., 34, 1149-1152, 1977.
Von Storch, H.: Misuses of statistical analysis in climate research, in: Analysis of climate variability, Springer-Verlag, Berlin, Heidelberg, 11-26, 1999.

Ward Jr., J. H.: Hierarchical grouping to optimize an objective function, J. Am. Stat. Assoc., 58, 236-244, 1963.

WHO: Review of evidence on health aspects of air pollution - REVIHAAP Project, available at: https: //www.euro.who.int/_data/assets/pdf_file/0004/193108/

REVIHAAP-Final-technical-report-final-version.pdf (last access: 7 January 2021), 2013.

Wild, O., Zhu, X., Prather, M., and Fast, J.: Accurate simulation of in-and below-cloud photolysis in tropospheric chemical models, J. Atmos. Chem, 37, 245-282, 2000.

Witha, B., Hahmann, A. N., Sile, T., Dörenkämper, M., Ezber, Y., Bustamante, E. G., Gonzalez-Rouco, J. F., Leroy, G., and Navarro, J.: Report on WRF model sensitivity studies and specifications for the mesoscale wind atlas production runs: Deliverable D4.3, NEWA - New European Wind Atlas, Zenodo, https://doi.org/10.5281/zenodo.2682604, 2019.

Yahya, K., Wang, K., Campbell, P., Glotfelty, T., He, J., and Zhang, Y.: Decadal evaluation of regional climate, air quality, and their interactions over the continental US and their interactions using WRF/Chem version 3.6.1, Geosci. Model Dev., 9, 671-695, https://doi.org/10.5194/gmd-9-671-2016, 2016.

Yang, Q., Gustafson Jr., W. I., Fast, J. D., Wang, H., Easter, R. C., Wang, M., Ghan, S. J., Berg, L. K., Leung, L. R., and Morrison, H.: Impact of natural and anthropogenic aerosols on stratocumulus and precipitation in the Southeast Pacific: a regional modelling study using WRF-Chem, Atmos. Chem. Phys., 12, 87778796, https://doi.org/10.5194/acp-12-8777-2012, 2012.

Yu, H., Kaufman, Y. J., Chin, M., Feingold, G., Remer, L. A., Anderson, T. L., Balkanski, Y., Bellouin, N., Boucher, O., Christopher, S., DeCola, P., Kahn, R., Koch, D., Loeb, N., Reddy, M. S., Schulz, M., Takemura, T., and Zhou, M.: A review of measurement-based assessments of the aerosol direct radiative effect and forcing, Atmos. Chem. Phys., 6, 613-666, https://doi.org/10.5194/acp-6-613-2006, 2006. 